\title{
Effect of Polymer Coating and Fungicide on Storage Performance of Kabuli Chickpea Varieties
}

\author{
B. Roopashree*, R.B. Jolli, Ashok S. Sajjan and B.N. Motagi
}

Department of Seed Science and Technology, College of Agriculture, Vijayapura 586101, University of Agricultural Sciences, Dharwad 580 005, Karnataka, India

*Corresponding author

\section{A B S T R A C T}

\begin{tabular}{|l|}
\hline Ke y w o r d s \\
Polymercoat, \\
$\begin{array}{l}\text { Fungicide, Kabuli, } \\
\text { Storage } \\
\text { performance }\end{array}$ \\
\hline Article Info \\
\hline $\begin{array}{l}\text { Accepted: } \\
\text { 08 August } 2018 \\
\text { Available Online: } \\
\text { 10 September } 2018\end{array}$ \\
\hline
\end{tabular}

A laboratory experiment was carried out in the Department of Seed Science and Technology, College of Agriculture, Vijayapura, University of Agricultural Sciences, Dharwad during 2017-18 to study the effect of seed polymer coating along with fungicide on seed quality parameters of kabuli chickpea varieties during storage. The variety MNK 1 showed better storage performance as compared to KAK 2. Among the seven different treatments viz., control, polymer $10 \mathrm{ml} / \mathrm{kg}$ seed, polymer $20 \mathrm{ml} / \mathrm{kg}$ seed, vitavax $3 \mathrm{~g} / \mathrm{kg}$ seed, polymer $(10 \mathrm{ml} / \mathrm{kg}$ of seed $)+$ vitavax power $(3 \mathrm{~g} / \mathrm{kg}$ of seed $)$, polymer $(20 \mathrm{ml} / \mathrm{kg}$ of seed) + vitavax power ( $3 \mathrm{~g} / \mathrm{kg}$ of seed) and castor oil $(10 \mathrm{ml} / \mathrm{kg}$ seed $)$ the kabuli chickpea seeds treated with polymer $(20 \mathrm{ml} / \mathrm{kg}$ of seed $)+$ vitavax power $(3 \mathrm{~g} / \mathrm{kg}$ of seed $)$ recorded significantly higher germination $(94.25 \%)$, shoot length $(11.29 \mathrm{~cm})$, root length $(17.74 \mathrm{~cm})$, seedling vigour index (2736), seedling dry weight $(519.18 \mathrm{mg} / 10$ seedlings), hundred seed weight $(45.21 \mathrm{~g})$, lower electrical conductivity $\left(0.757 \mathrm{dSm}^{-1}\right)$ and no insect damage upto nine months of storage followed by the treatment combination polymer $(10 \mathrm{ml} / \mathrm{kg}$ of seed $)$ + vitavax power $(3 \mathrm{~g} / \mathrm{kg}$ of seed). Hence the same treatment combination can be used to store seeds for longer period without much deterioration.

\section{Introduction}

Chickpea (Cicer arietinum L.) is an important legume, which belongs to the genus Cicer, family Fabaceae. The southeastern part of Turkey near Syria was the place where chickpea is accepted to have been originated (Van Der Maesen, 1984). There are two kinds of chickpea viz., desi and kabuli grown in the world. Kabuli type is grown in temperate regions, while the desi type chickpea is grown in the semi-arid tropics (Muehlbauer and Singh, 1987; Malhotra et al., 1987). Karnataka is one of the important chickpea producing states in the country, where it is cultivated extensively in northern Karnataka especially in Vijayapura, Kalaburagi, Dharwad, Belgavi, Gadag, Bagalkot, Raichur and Bidar districts. In Karnataka, it is grown over an area of 1.37 million hectares with a production of 0.90 million tonnes at an average productivity of $654 \mathrm{~kg}$ per hectare (Anon., 2016). In India, kabuli types occupy nearly 15 per cent and desi type occupies about 85 per cent of area. Kabuli chickpea has good market value as compared to desi chickpea but due to its 
bigger size, they have exceptionally thin and smooth seed coat and higher protein and sugar contents which make them profoundly vulnerable to pests and pathogens and may increase the concentration and extent of leachate as well, which utimately losses its viability. Thus, it needs more specific storage conditions to produce a good quality seeds.

The polymer coating with the negligible thickness of $84 \mu$ over the seed coat gives protection from the imposed accelerated ageing, which include fungal invasion. It decreases the wastage of chemicals and helps to incorporate all required nutrients, oxygen suppliers and also protect the seed from fungal invasion and insects attack. Seed coatings with natural or synthetic polymers and fungicide have picked up fast acceptance by the seed industry as a much safer coating material. The polymer coating allows slight moisture content fluctuations during storage. Better storage performance can be obtained by treating the seeds with polymers + fungicide and storing them under ambient conditions with minimum qualitative and quantitative changes, keeping this in view an experiment was conducted to know the effect of polymer coating and fungicide treatment on storability of kabuli chickpea varieties.

\section{Materials and Methods}

The storage experiment was carried out during 2017-18 consisting of two varieties and seven treatments. The kabuli chickpea varieties viz., KAK 2 and MNK 1 were obtained from Plant breeder AICRP, Dryland Agriculture, RARS Vijayapura. Seeds were treated in accordance of treatment combinations viz., $\mathrm{T}_{1}$ : control (Untreated), $\mathrm{T}_{2}$ : polymer coat $10 \mathrm{ml} / \mathrm{kg}$ seed, $\mathrm{T}_{3}$ : polymer coat $20 \mathrm{ml} / \mathrm{kg}$ seed, $\mathrm{T}_{4}$ : vitavax power $3 \mathrm{~g} / \mathrm{kg}$ seed, $\mathrm{T}_{5}$ : polymer coat $10 \mathrm{ml} / \mathrm{kg}$ seed + vitavax power $3 \mathrm{~g} / \mathrm{kg}$ seed, $\mathrm{T}_{6}$ : polymer coat $20 \mathrm{ml} / \mathrm{kg}$ seed + vitavax power $3 \mathrm{~g} / \mathrm{kg}$ seed, $\mathrm{T}_{7}$ : castor oil $10 \mathrm{ml} / \mathrm{kg}$ seed. One $\mathrm{kg}$ kabuli chickpea seeds were taken in a polythene bags and $10 \mathrm{ml}$ and $20 \mathrm{ml}$ of polymer per $\mathrm{kg}$ seed was added to it separately as per the treatment. Whereas, vitavax power $3 \mathrm{~g} / \mathrm{kg}$ seed was made into slurry and added to separate polythene bags and closed tightly trapping the air in it to form a balloon, then polythene bag was vigorously shaken till the seeds are uniformly coated, later the treated seeds were spread on a polythene sheet to dry under the shade. One $\mathrm{kg}$ of seeds were taken in a polythene bag, initially they are treated with fungicide (vitavax power) and then added polymer coat in it. The polythene bag was closed tightly trapping air in it to form a balloon and vigorously shaken till the seeds were uniformly coated, later the treated seeds were spread on a polythene sheet under the shade to dry completely and packed in cloth bag. The packed seeds were kept for storage under ambient conditions. The same procedure was used for the other seed treatment combinations also. Observations on seed quality parameters like seed germination (\%), root length $(\mathrm{cm})$, shoot length $(\mathrm{cm})$, seedling vigour index, seedling dry weight $(\mathrm{mg} / 10$ seedlings), electrical conductivity $\left(\mathrm{dSm}^{-1}\right)$, hundred seed weight $(\mathrm{g})$ and insect damage (\%) were recorded every month upto 9 months of storage period. The data collected from the experiment was analysed statistically by adopting the procedures as described by Sundarrajan et al., (1972).

\section{Results and Discussion}

The varietal differences with respect to storage performance have been observed in kabuli chickpea varieties (Table 1 and 2). Significant variation in the parameters was observed in kabuli chickpea varieties irrespective of treatments. Significantly higher germination (90.18\%) was recorded in MNK 1 as compared to KAK $2(88.46 \%)$ at the end of storage period. Retention of higher germination in MNK 1 may be due to 
genotypic factor, seed size and its stored reserves (Hojjat, 2011). Such varietal variation with respect to germination was reported by Upadhayay et al., (2002) in chickpea. However, significantly higher root length $(16.50 \mathrm{~cm})$, shoot length $(10.82 \mathrm{~cm})$, vigour index (2470) and seedling dry weight (541.41mg) were noticed in MNK 1 at the end of storage period. Amount of reserve food material mobilized which ultimately contributed to longer seedling length, higher seedling dry weight as well as vigour index. Differential decrease in all these vigour parameters in kabuli chickpea varieties during storage may ascribed due to their genetic differences existing and age induced deterioration at various degrees with the increase in the storage period (Delouche, 1973). Similar decrease in seedling vigour parameters with the advancement in the storage period were reported by Kapoor et al., (2010) in chickpea. In the present study, the hundred seed weight was maximum in MNK 1 in all months of storage period than KAK 2 due to its larger size. Similar results were reported by Gnyandev (2009) in chickpea. The different electrical conductivity values recorded between the varieties indicate that membrane integrity is lost during seed ageing, the nature and extent of membrane damage may not be similar for all the varieties and thus differences in electrical conductivity values are bound to occur (Kurdikeri, 1991). In the present study, the mean electrical conductivity of seed leachate values was higher $\left(0.937 \mathrm{dSm}^{-1}\right)$ in MNK 1 at nine months of storage period due to its extra bold nature of seed and more food reserves. Similar variation in electrical conductivity was noticed by Merwade (2000) in chickpea. The higher per cent infestation was recorded in MNK 1 variety may be due to the higher protein and sugar content, thin smooth and white coloured testa of kabuli type chickpea. In the beginning of the storage period, per cent infestation was zero and with advancement of storage period, increase in infestation was seen. This difference may be due to variation in inherent genotypic composition to withstand the impact of pest infestation. These results are in agreement with the reports of Gnyandev (2009) in chickpea

The seed germination per cent of kabuli chickpea seeds declined progressively with increase in the period of storage in all the treatment combinations, which may be attributed to the phenomenon of natural ageing and depletion of food reserves and decline in metabolic activity of seed due to respiration. The germination was significantly higher $(94.25 \%)$ in the seeds treated with vitavax power@3 g/kg seed + polymercoat @ 20 $\mathrm{ml} / \mathrm{kg}$ of seed and 93.13 per cent in vitavax power @ $2 \mathrm{~g} / \mathrm{kg}$ seed + polymercoat @ 10 $\mathrm{ml} / \mathrm{kg}$ of seed. These treatments are above the level of Indian minimum seed certification standard $(85 \%)$ for chickpea. Significantly, lowest germination $(83.63 \%)$ was noticed in the untreated at the end of storage period. Higher germination percentage can be seen in treated seeds and it may be due to pathogen and pest suppressive nature of chemicals. In general vitavax power reduces the impact of ageing enzymes, seed deterioration due to fungal invasion and physiological ageing as a result. Polymer film may acts as physical barrier, which has been reported to reduce the leaching of inhibitors from the seed coverings and may restrict oxygen diffusion to embryo. So the seed viability was maintained for a comparatively longer period of time. These finding are in agreement with results obtained by Baig (2005) in soybean and Junior et al., (2012) in soybean. At the end of ninth month of storage period, significantly higher shoot length $(11.29 \mathrm{~cm})$ was recorded in vitavax power @ $3 \mathrm{~g} / \mathrm{kg}$ seed + polymer seed coating @ $20 \mathrm{ml} / \mathrm{kg}$ of seeds followed by vitavax power@3 g/kg seed + polymercoat @ 10 $\mathrm{ml} / \mathrm{kg}$ of seeds as $11.08 \mathrm{~cm}$ and the lower shoot length $(9.63 \mathrm{~cm})$ was observed in untreated. 
Table.1 Effect of polymer coating and fungicide treatment on seed germination (\%), shoot length (cm), root length (cm), seedling vigour index and seedling dry weight (mg/10seedlings) of kabuli chickpea varieties during storage period

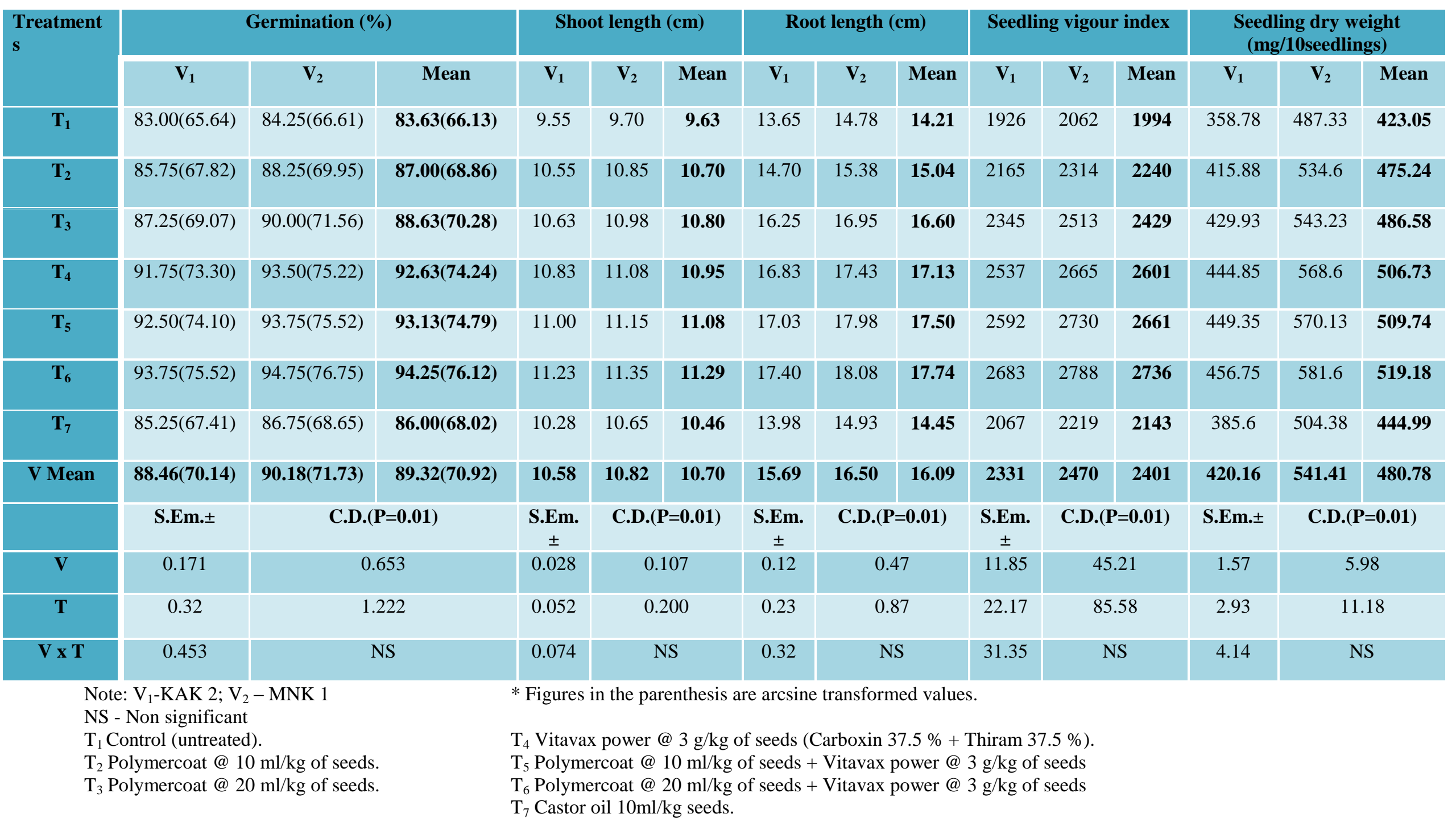


Table.2 Effect of polymer coating and fungicide treatment on hundred seed weight ( $\mathrm{g}$ ), electrical conductivity $\left(\mathrm{dSm}{ }^{-1}\right)$, seed moisture content $(\%)$ and insect damage (\%) of kabuli chickpea varieties during storage period

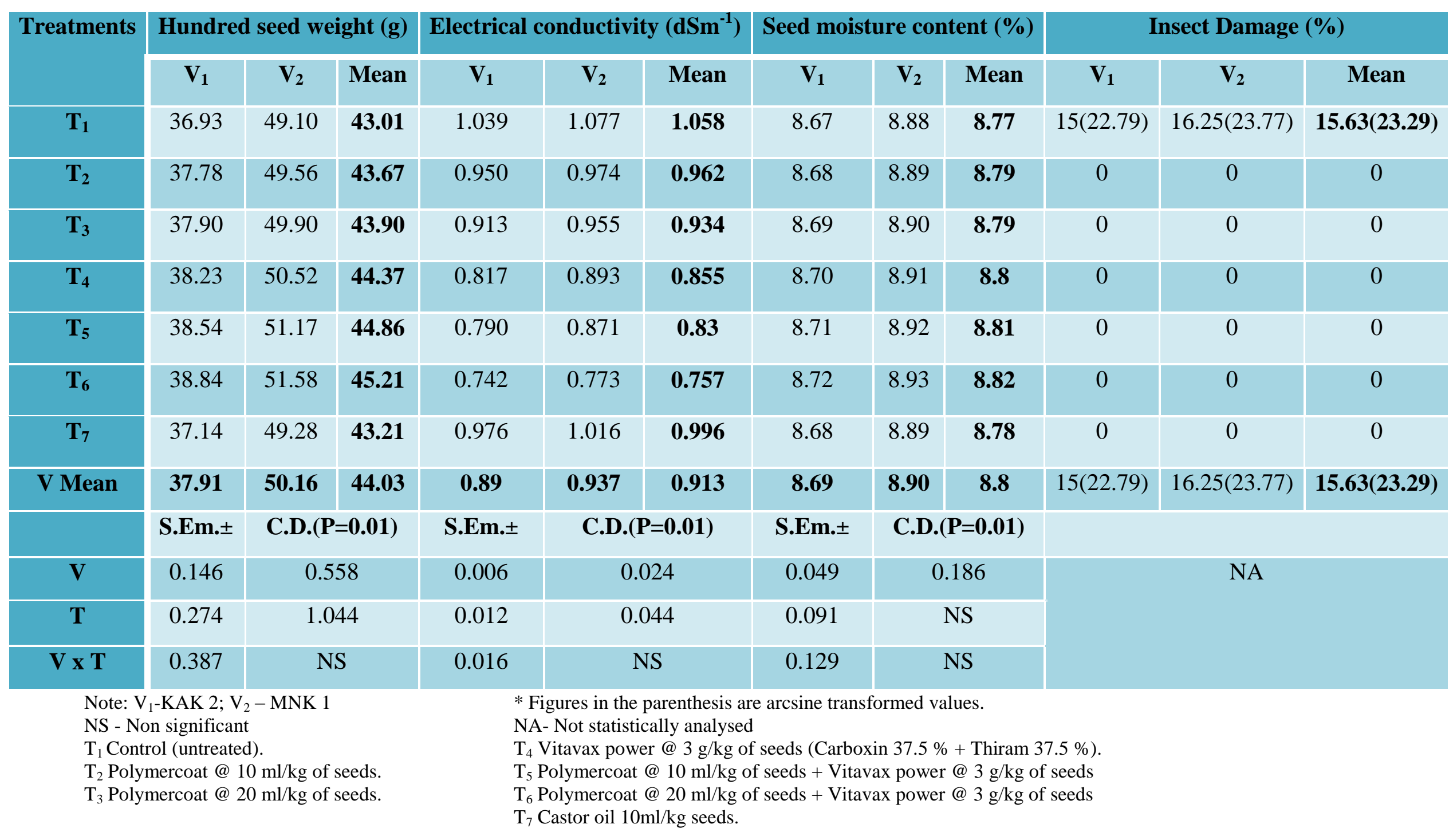


Similarly, higher root length $(17.74 \mathrm{~cm})$ was noticed in vitavax power @3 g/kg seed + polymercoat @20 ml $/ \mathrm{kg}$ of seeds and it was on par with vitavax power @ $3 \mathrm{~g} / \mathrm{kg}$ seed + polymercoat @ $10 \mathrm{ml} / \mathrm{kg}$ of seeds $(17.50 \mathrm{~cm})$. While, significantly lower root length was recorded in untreated $(14.21 \mathrm{~cm})$. The shoot length and root length of polymer coated seeds with fungicide were more compared to the uncoated seeds. It is due to higher germination and healthy seedlings in seed coated with polymer and fungicide as this protected from fungi invasion and there by good and better germination and subsequent higher root and shoot length was produced. Similar results were also reported by Baig (2005) in Soybean and Kaushik et al., (2014) in maize.

In the present study, significantly higher vigour index was recorded in vitavax power @ $3 \mathrm{~g} / \mathrm{kg}$ seed + polymer coat @ $20 \mathrm{ml} / \mathrm{kg}$ of seeds) as 2736 and it was on par with vitavax power @ $3 \mathrm{~g} / \mathrm{kg}$ seed + polymer coat @ 10 $\mathrm{ml} / \mathrm{kg}$ of seeds as 2661. While, significantly lower vigour index (1994) was recorded in untreated. Dry weight of seedling decreased with increase in the storage period. This may be due to ageing and deterioration of seed, decrease in the germination percentage and seedling length. Among the treatment combinations the seeds treated with vitavax power@ 3 g/kg seed + polymercoat @ 20 $\mathrm{ml} / \mathrm{kg}$ of seeds recorded significantly higher seedling dry weight $(519.18 \mathrm{mg})$ followed by vitavax power@ $3 \mathrm{~g} / \mathrm{kg}$ seed + polymercoat @ $10 \mathrm{ml} / \mathrm{kg}$ of seeds (509.74 mg). While, the significantly lower seedling dry weight was recorded in untreated as $423.05 \mathrm{mg}$ at the end of ninth month of storage period. This decrease in dry weight and seedling vigour index was due to decrease in germination percentage, seedling length, it leads to the lower seed vigour index and dry weight. Seed coated with the polymer combined with fungicide gave better results due to good germination percentage. Higher seedling length, seedling dry weight and vigour index. These results are in conformity with the findings of Baig (2005) in soybean and Kaushik et al., (2014) in maize.

Significantly higher hundred seed weight $(45.21 \mathrm{~g})$ was recorded in vitavax power @ 3 $\mathrm{g} / \mathrm{kg}$ seed + polymercoat @ $20 \mathrm{ml} / \mathrm{kg}$ of seeds) followed by vitavax power @ $3 \mathrm{~g} / \mathrm{kg}$ seed + polymercoat @ $10 \mathrm{ml} / \mathrm{kg}$ of seeds $(44.86 \mathrm{~g})$, while significantly lower hundred seed weight $(43.01 \mathrm{~g})$ was recorded in untreated. The decrease in the hundred seed weight was observed as the storage period increased. This may be due to fluctuation of seed moisture content during storage, infestation of the insects, which will feed both internally and externally and also due to activity of the fungi. These results are similar to the findings of Siddaraju et al., (2015) in hybrid maize.

A number of water soluble compounds such as sugars, amino acids and organic acids are released when seeds were soaked in water. The electrical conductivity of seed leachate indicates the membrane integrity and quality of seed and it was negatively correlated with seed quality. In the present investigation significantly lower electrical conductivity $\left(0.757 \mathrm{dSm}^{-1}\right)$ was recorded in vitavax power $3 \mathrm{~g} / \mathrm{kg}$ seed + polymercoat $20 \mathrm{ml} / \mathrm{kg}$ of seed and it was followed by vitavax power $3 \mathrm{~g} / \mathrm{kg}$ seed + polymercoat $10 \mathrm{ml} / \mathrm{kg}$ of seed 0.830 $\mathrm{dSm}^{-1}$, while significantly higher electrical conductivity was recorded in untreated (1.058 $\mathrm{dSm}^{-1}$ ) at the end of storage period. This variation in electrical conductivity of seed leachate indicating that increased membrane permeability and decreased compactness of seed coat and cellular membrane deterioration. Similar, findings were reported by Baig (2005) in soybean. The polymer film formed around seed acts a physical barrier, which has been reported to reduce leaching of 
inhibitors from seed covering and may restrict oxygen diffusion to the embryo (Vanangamudi et al., (2003). The stable cell membrane also rendered resistance to peroxidase and free radical reactions and vitavax power acted as antifungal agent and anti oxident agent. There was no insect infestation in the seeds treated with polymer coat, fungicide and castor oil. Seeds coated with liquid polymer creates smooth surface on seed coat so there is no choice to lay eggs on seed coat. Similar results were reported by (Suresh, 2008) in maize and Chowdhury et al., (2012) in soybean.

It can be concluded from the results that, MNK 1 seeds store better during a period of storage with good seed quality than the KAK 2. Large quantity of seed can be stored for longer period, with superior seed quality by treating the seeds with vitavax power $3 \mathrm{~g} / \mathrm{kg}$ seed + polymercoat $20 \mathrm{ml} / \mathrm{kg}$ of seed.

\section{References}

Anonymous, 2016, Agricultural statistics at a glance 2016, Department of Agriculture, Cooperation and Farmers Welfare, Directorate of Economics and Statistics, pp. 109-111.

Baig, I., Biradar Patil, N. K., Ninganur, B. T., Patil, R. H. and Hunje, R., 2005, Effect of grading methods, fungicides and polymer coating on storability of soybean (Glycine $\max$ (L.) Merrill). M.Sc. (Agri.) Thesis, Univ. Agric. Sci., Dharwad, Karnataka (India).

Chowdhury, A. R., Kumar. J., Shakil, N. A., Walia, S., Srivastava, C. and Jha, A. N., 2012, Evaluation of Repellency and Oviposition Deterrency of Anothocyanin and Azadirachtin Based Coloured Polymeric Seed Coats Against Storage Pest Of Soybean. Ann. Pl. Prot. Sci., 20(1): 42-46.
Delouche, J. C., 1973, Precepts of seed storage (Revised) South Canada Proc., Mississippi State Univ., pp. 97-122.

Gnyandev, B., 2009, Seed technological studies in chickpea varieties (Cicer arietinum L.) Ph.D. Thesis, Univ. Agric. Sci., Dharwad, Karnataka, India.

Hojjat, S. S., 2011, Effect of seed size on germination and seedling growth of some lentil genotypes. Int. J. Agric. Crop Sci., 3: 45.

Junior, J. C. B., Barros, A. C. S. A., Tavares, L. C., Rufino, C. A., Tunes, L. V. M. and Meneghello, G. E., 2012, Physiological quality of soybeans seeds treated with fungicide and coating with polymers. Brazilian J. Agric. Sci., 7 (2): 269-273.

Kapoor, N., Arya, A., Siddique, M. A., Amir, A. and Kumar, H., 2010, Seed deterioration in chickpea (Cicer arietinum) under accerlated ageing. Asian J. Pl. Sci., 9(3):58-162.

Kaushik, S. K., Rai, K. and Singh, H. V., 2014, Seed quality of maize with polymer film coating in storage. Int. J. Inn. Res. Sci. Eng. Tech., 3(7): 335-340.

Kurdikeri, M. B., 1991, Studies on seed quality in hybrid maize (Zea mays L.). Ph.D. Thesis, Univ. Agric. Sci., Bangalore, Karnataka (India).

Merwade, M. N., 2000, Investigations on seed production techniques on storability of chickpea (Cicer arietinum L.). Ph.D. Thesis, Univ. Agric. Sci., Dharwad, Karnataka (India).

Muehlbauer, F. J. and Singh, K. B. (1987), Genetics of chickpea. In "The Chickpea", Eds. M.C. Saxena and K.B. Singh, CAB. International, Wallingford, Oxon, OX10 8DE, UK, pp. 99-125.

Siddaraju, R., Narayanaswamy, S. and Ramanappa, T. M., 2015, A study on the effect of seed coating with synthetic polymer and seed treatment chemicals on physiological changes and seed 
infestation of maize hybrid Hema (Zea mays L.) during seed storage. Mysore $J$. Agric. Sci., 49(3): 467-477.

Sundarajan, N., Nagraju, S., Venktataraman, S. and Jaganath, M. H., 1972, Design and Analysis of field experiments. Univ. Agril. Sci., Bangalore.

Suresh, V. and Renganayaki, P. R., 2008, Standardization of Polymercoating technology for mechanization in maize hybrid COH (M) 5 M.Sc. (Agri.) Thesis, Tamil Nadu Agric. Univ., Coimbatore, Tamil Nadu (India).

Upadhayay, H. D., Qrtiz, R., Paula, J. B. and Singh, S., 2002, Phenotypic diversity for morphological and agronomic characteristics in chickpea core collection. Euphytica, 123: 333-342.

Van Der Maesen, L. J. G., 1984, The chickpea In: Genetics, Cytogenetics and Breeding of Crop Plants, Vol.- I: Pulses and Oilseeds.(Ed.: Bahl, P. N. and Salimath, P. M.,1996), Oxford and IBH Publ. Comp. Pvt. Ltd., New Delhi, p. 4. Vanangamudi, K., Srimathi, P., Natarajan, N. and Bhaskaran, M., 2003, Current scenario of seed coating polymer. ICAR - Short Course on Seed Hardening and Pelleting Technologies for Rain Fed or Garden Land Ecosystems, pp: 80-100.

\section{How to cite this article:}

Roopashree, B., R.B. Jolli, Ashok S. Sajjan and Motagi, B.N. 2018. Effect of Polymer Coating and Fungicide on Storage Performance of Kabuli Chickpea Varieties. Int.J.Curr.Microbiol.App.Sci. 7(09): 954-961. doi: https://doi.org/10.20546/ijcmas.2018.709.115 